\title{
Evaluasi Ketersediaan Ruang Udara dalam Kaitannya dengan Keselamatan Operasional Penerbangan di Bandara Abdul Rachman Saleh
}

\author{
Dimita Brilian Zahra, Ervina Ahyudanari, Istiar \\ Departemen Teknik Sipil, Fakultas Teknik Sipil dan Perencanaan, Institut Teknologi Sepuluh \\ Nopember (ITS) \\ E-mail: ervina@ce.its.ac.id
}

\begin{abstract}
Abstrak - Dilihat dari letak topografi, Daerah dataran rendah Kabupaten Malang terletak pada ketinggian 250m dpl sampai dengan 500m dpl. Secara fisik, letak Bandara Abdul Rachman Saleh berada di Kecamatan Pakis Kabupaten Malang atau 17 km arah Timur dari pusat Kota Malang. Bandara ini berada di lembah Bromo dan dikelilingi oleh beberapa gunung yaitu Gunung Semeru (3676m) di sebelah Timur, Gunung Arjuno (3339m) di sebelah Utara, Gunung Kawi (2551m) dan Gunung Panderman $(2000 \mathrm{~m})$ di sebelah Barat. Sehingga, perlu diperhatikan keselamatan operasional penerbangan akibat pergerakan pesawat terkait dengan terbatasnya ruang udara. Dalam Studi ini, dilakukan evaluasi pola pergerakan pesawat terhadap topografi dan kawasan operasi penerbangan Bandara Abdul Rachman Saleh.Selain itu juga dilakukan evaluasi kapasitas dan berat masing-masing pesawat terbang yang beroperasi terhadap ruang udara yang tersedia, dalam hal ini berkaitan dengan jarak tempuh pesawat dan panjang runway yang tesedia, konsumsi bahan bakar pesawat serta kondisi cuaca yang ada di sekitar bandar udara.Dari hasil analisis yang dilakukan, didapatkan hasil pada arah memanjang runway, kawasan keselamatan operasi penerbangan Bandara Abdul Rachman Saleh terhadap topografi memenuhi syarat dan menjamin keselamatan operasional. Pada arah melintang runway, kawasan operasi penerbangan Bandara Abdul Rachman Saleh terhadap topografi tidak memenuhi, karena elevasi topografi lebih tinggi dari pada batas elevasi kawasan keselamatan operasi penerbangan (KKOP) Bandara dan pergerakan masing-masing pesawat tidak mengalami gangguan keselamatan operasional terhadap topografi. Dalam radius destinasi $377 \mathrm{~nm}$ pesawat dapat menghabiskan bahan bakar sebesar 7365 liter sehinggakonsumsi bahan bakar pesawat per panjang destinasi yag ditempuh adalah 19,54 liter/nautical miles. Sehingga fuel cadangan yang diperlukan oleh pesawat adalah 2286 liter.Dan dengan kapasitas 25 pergerakan per jam di Bandara kondisi cuaca pada pagi hari dengan suhu rata-rata $27^{\circ}$, jarak pandang $7,1 \mathrm{~km}$ dan waktu tempuh efektif selama 45 menit.
\end{abstract}

Kata Kunci-Ruang Udara, Keselamatan Operasional Penerbangan, Topografi Bandara, Faktor Cuaca.

\section{PENDAHULUAN}

$\mathrm{K}$ EMACETAN yang sering terjadi di beberapa kota di Provinsi Jawa juga dirasakan oleh masyarakat Kabupaten Malang yang merupakan Kabupaten terluas kedua di Jawa Timur.Kabupaten Malang dikenal sebagai salah satu daerah tujuan wisata utama di Jawa Timur.Sebagian besar Wilayah Kabupaten Malang adalah kawasan dataran tinggi dan pegunungan.Wisatawan yang berkunjung ke Kabupaten Malang tidak hanya berasal dari Jawa Timur, terutama dari luar Jawa Timur.Diantaranya menggunakan jasa transportasi darat ataupun transportasi udara.

Transportasi udara merupakan alat angkutan tercepat dibandingkan dengan transportasi darat atapun laut. Bandara Abdul Rachman Saleh adalah Bandar Udara yang terletak di Kabupaten Malang memegang peran penting bagi para wisatawan dan masyarakat Provinsi Jawa Timur dalam melakukan perkembangan ekonomi serta merupakan salah satu gerbang masuk menuju Jawa Timur.

Bandara Abdul Rachman Saleh memiliki landasan pacudengan panjang eksisting 2250m dan melayani Pesawat terbesar tipe Boeing 737-800NG dengan penerbangan terjauh adalah Bandara Soekarno Hatta, Cengkareng, Tangerang.Bandara Abdul Rachman Saleh merupakan bandara yang unik karena merupakan satu-satunya bandara yang dikelola Pemerintah Provinsi Jawa Timur, dan Bandara lainnya yaitu Bandara Blimbingsari, Bandara Notohadinegoro dikelola oleh Pemerintah Kabupaten Setempat. Serta Bandara Internasional Juanda dikelola oleh PT. Angkasa Pura.

Dilihat dari letak topografi, daerah dataran rendah Kabupaten Malang terletak pada ketinggian 250m dpl sampai dengan 500m dpl. Secara fisik, letak Bandara Abdul Rachman Saleh berada di Kecamatan Pakis Kabupaten Malang atau $17 \mathrm{~km}$ arah Timur dari pusat Kota Malang.Bandara Abdul Rachman Saleh dibangun oleh pemerintahan Belanda pada era 1937-1940. Bandara ini berada di lembah Bromo dan dikelilingi oleh beberapa gunung yaitu Gunung Semeru (3676m) di sebelah Timur, Gunung Arjuno (3339m) di sebelah Utara, Gunung Kawi (2551m) dan Gunung Panderman (2000m) di sebelah Barat. Sehingga, perlu diperhatikan keselamatan operasional penerbangan akibat pergerakan pesawat terkait dengan terbatasnya ruang udara.

Dengan demikian, mengetahui keselamatan operasional di Bandara Abdul Rachman Saleh sangat diperlukan dengan cara mengevaluasi kesesuaian kebutuhan ruang udara terhadap keselamatan operasi.

\section{METODOLOGI}

Untuk menyelesaikan permasalahan yang ada dalam Studi ini, perlu dilakukan beberapa tahapan kerja.Tahapan tersebut meliputi tahap persiapan, studi pustaka, pengumpulan data, analisis data dan pengambilan suatu kesimpulan dari studi yang dilakukan. Tahapan - tahapan tersebut dijelaskan dalam sub bab - sub bab berikut ini agar dapat lebih memberikan gambaran yang lebih jelas mengenai proses penyelesaian masalah dalam studi ini. 


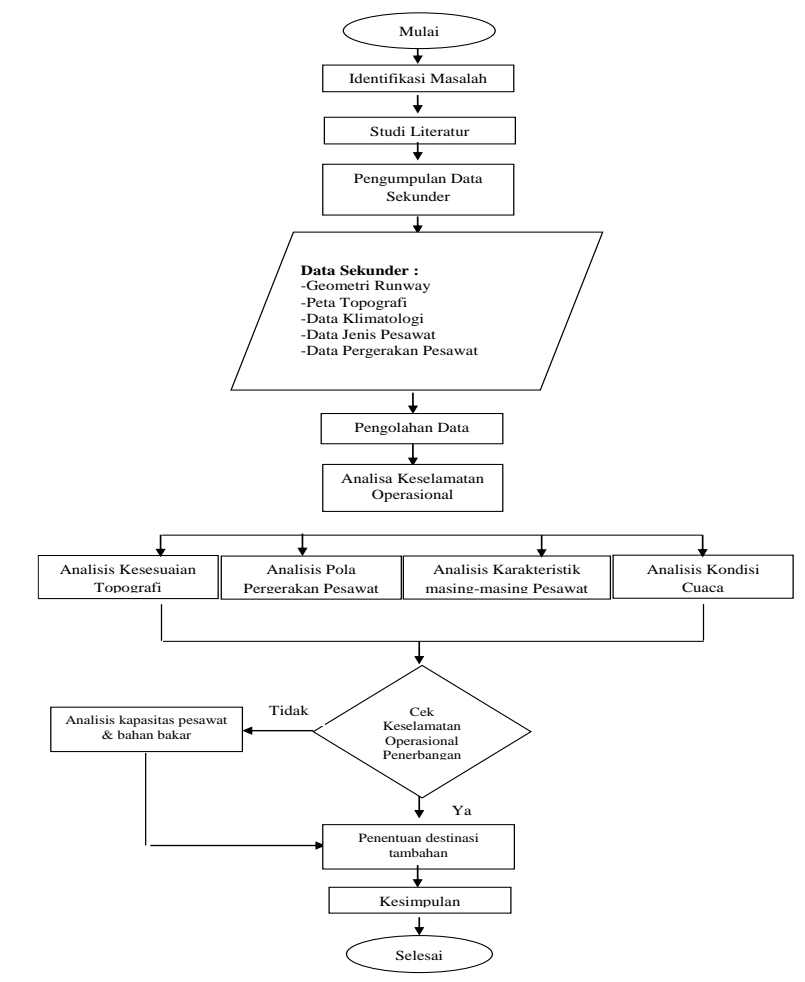

Gambar 1. Diagram Alir Metodologi Evaluasi

\section{HASIL DAN PEMBAHASAN}

\section{A. Analisis Runway}

Guna mengetahui panjang runway aktual yang dibutuhkan pesawatyang beroperasi di Bandara Abdul Rachman Saleh, perlu beberapa koreksi terhadap faktor elevasi, temperatur, dan slope (kelandaian) runway.Untuk menghitung faktor koreksi, terlebih dahulukan harus mencari ARFL.ARFL adalah panjang landasan minimum bagi pesawat untuk take off pada keadaan standar, yaitu pada kondisi MTOW(Maximum Take-Off Weight), ketinggian nol terhadap permukaan air laut, kondisi atmosfer standar, keadaan tanpa angin, dan kemiringan runway nol. Nilai ARFL (Aerodrome Reference Field Length)didapat dari pabrik pembuat pesawat bersangkutan. Adapun ARFL pesawat Boeing 737-800 NG adalah 2878 m [1].

Perhitungan koreksi terhadap runway berdasarkan metoda ICAO sebagai berikut:

$>$ Koreksi terhadap Elevasi (KE)

$\mathrm{KE}=\left[\mathrm{ARFL} \times 7 \% \times \frac{\text { elevasi runway }}{300}\right]+\mathrm{ARFL}$

$\mathrm{KE}=\left[2878 \times 7 \% \times \frac{528}{300}\right]+2878$

$\mathrm{KE}=3232,57 \mathrm{~m}$

Koreksi terhadap Elevasi Temperature (KET)

$\mathrm{KET}=\{\mathrm{KE} \times$ [temperatur $-(15-0,0065 \times \mathrm{h})]\} \times 1 \%+\mathrm{KE}$ $\mathrm{KET}=\{3232,57 \times[24-(15-0,0065 \times 528)]\} \times 1 \%+3232,57$

$\mathrm{KET}=3634,44 \mathrm{~m}$

Koreksi terhadap Elevasi, Temperatur dan Slope (KETS)

KETS $=[$ KET $x$ slope $\times 10 \%]+$ KET

$\mathrm{KETS}=[3634,44 \times 1,6 \% \times 10 \%]+3634,44$

KETS $=3640 \mathrm{~m}$

Dengan mempertimbangkan faktor keamanan dan kemudahan pengerjaan maka panjang runwayaktual, atau yang juga dikenal sebagai TORA (Take-off Run Available) adalah 3640m. Panjang runway eksisting di Bandara Abdul Rachman Saleh saat ini adalah 2250m, sehingga perlu dilakukan penambahan panjang runway sebesar 1390m agar pesawat yang mempunyai ARFL 2879 dapat menggunakan runway.

Dapat dilihat pada Tabel 4.2 Bandara Abdul Rachman Saleh memiliki pesawat kritis yang digunakan adalah jenis pesawat Boeing 737-800 NG.Dan dapat diketahui bahwa ARC pesawatkritis adalah 4C. Dari Tabel dapat diketahui lebar runway adalah $40 \mathrm{~m}$.

Tabel 1.

Lebar runway berdasarkan code number [1].

\begin{tabular}{|c|c|c|c|c|c|c|}
\hline \multirow{2}{*}{ Code Number } & \multicolumn{6}{|c|}{ Code letter } \\
\cline { 2 - 7 } & A & B & C & D & E & F \\
\hline $1 \mathrm{a}$ & $18 \mathrm{~m}$ & $18 \mathrm{~m}$ & $23 \mathrm{~m}$ & - & - & - \\
\hline 2 & $23 \mathrm{~m}$ & $23 \mathrm{~m}$ & $30 \mathrm{~m}$ & - & - & - \\
\hline 3 & $30 \mathrm{~m}$ & $30 \mathrm{~m}$ & $30 \mathrm{~m}$ & $45 \mathrm{~m}$ & - & - \\
\hline 4 & - & - & $45 \mathrm{~m}$ & $45 \mathrm{~m}$ & $45 \mathrm{~m}$ & 60 \\
\hline
\end{tabular}

A. Analisis Kawasan Keselamatan Operasi Pernerbangan (KKOP) dengan Topografi

Pada tabel 2 merupakan batas KKOP bedasarkan klasifikasi runway [2].

Tabel 2.

Dimensi KKOP berdasarkan klasifikasi runway [3].

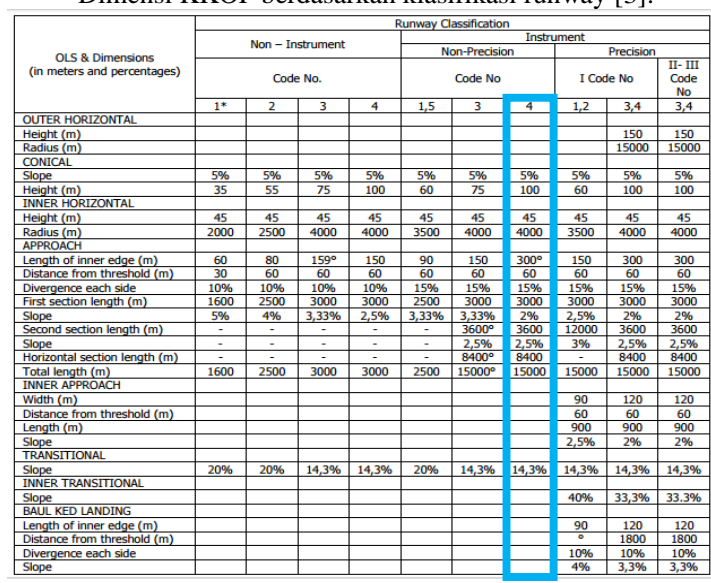

Bandara Abdul Rachman Saleh dalam merencanakan desain runwaydigunakanNon-Precision Approach Runways dengan pesawat kritis kategori 4C, spesifikasi KKOP disesuaikan dengan ketentuan pada tabel 4.5 di atas, dan dengan uraian sebagai berikut:

1) Kawasan Pendekatan Lepas Landas (Approach)[2].

Kawasan ini dibatasi oleh tepi dalam yang berhimpit dengan ujung-ujung permukaan utama berjarak 60 meter dari ujung landasa pacu dengan lebar bagian dalam, kawasan ini melebar kearah luar secara teratur dengan sudut pelebaran $15 \%$ serta garis tengah bidangnya merupakan perpanjangan dari garis tengah landas pacu dengan jarak mendatar pertama adalah $3000 \mathrm{~m}$ dengan kemiringan ketinggian dari landas pacu adalah $2 \%$, jarak mendatar kedua adalah $3600 \mathrm{~m}$ dari jarak mendatar pertama dengan kemiringan $2.5 \%$, dan jarak menatar ketiga adalah 8400 dari jarak mendatar kedua dengan kemiringan $2.5 \%$ sehingga jumlah jarak mendatar keseluruhan adalah $15000 \mathrm{~m}$ dengan lebar akhir kawasan ini adalah $4800 \mathrm{~m}$. Gambar dari kawasan pendekatan lepas landas sebagai berikut pada gambar 2 . 


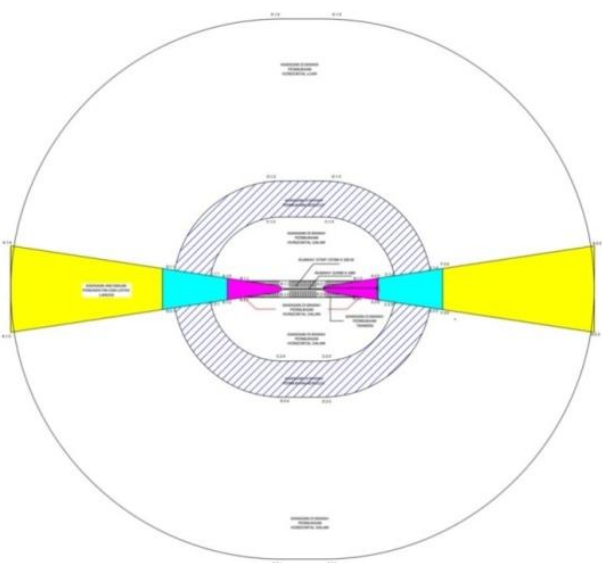

Gambar 2. Kawasan Pendekatan Lepas Landas

2) Kawasan Kemungkinan Bahaya Kecelakaan [2].

Kawasan ini dibatasi oleh tepi dala yang berhimpit dengan ujung-ujung permukaan utama dengan lebar 300 meter, kawasan ini meluas keluar secara teratur dengan garis tengahnya merupakan perpanjangan dari garis tengah landasan pacu sampai lebar 1200 meter dan jarak mendatar 3000 meter dari ujung permukaan utama.Kawasan kemungkinan bahaya kecelakaan sebagai berikut padagambar 3 berikut.

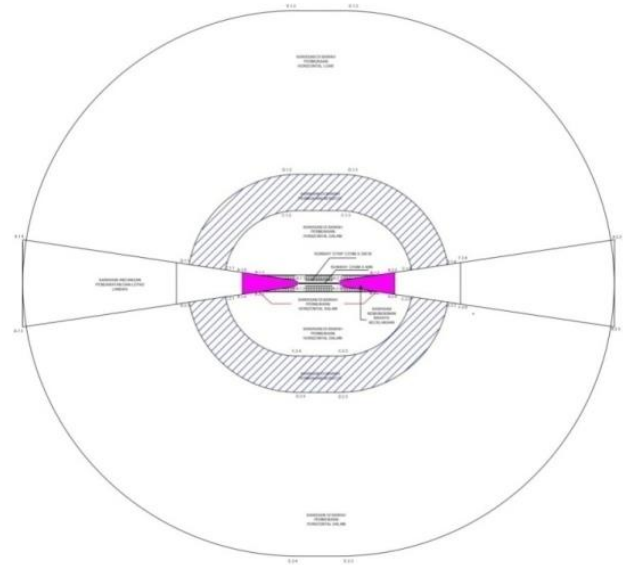

Gambar 3.Kawasan kemungkinan bahaya kecelakaan

3) Kawasan Keselamatan Operasi Penerbangan [2].

Kawasan keselamatan operasi penerbangan diwujudkan/berada dalam sistem koordinat bandar udara (Aerodrome Coordinate System/ACS) dan sistem koordinat geografis dalam referensi Word Geodetic System 1984 (WGS'84).Kawasan operasi penerbangan secara keseluruhan pada gambar 7 .

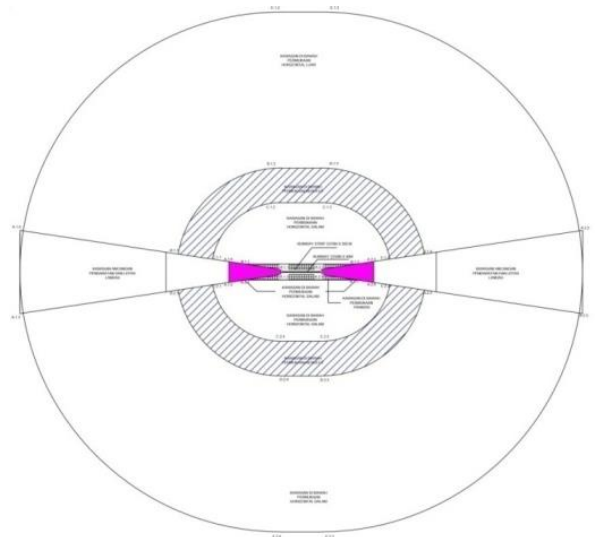

Gambar 7. Kawasan keselamatan operasi penerbangan
Batas ketinggian KKOP dan elevasi topografi pada potongan memanjang dan melintang KKOP dapat digabungkan sehingga dapat diketahui dengan jelas kenampakan KKOP terhadap topografi Bandara Abdul Rachman Saleh.Pada gambar 8 dan gambar 9 merupakan potongan memanjang dan melintang yang tergambar dari hasil evaluasi KKOP dan topografi. Pada gambar 8 menunjukkan bahwa elevasi topografi tidak melebihi batas ketinggian kawasan keselamatan operasi Bandara Abdul Rachman Saleh.Pada gambar 9 menunjukkan bahwa elevasi topografi melebihi batas kawasan keselamatan operasional.

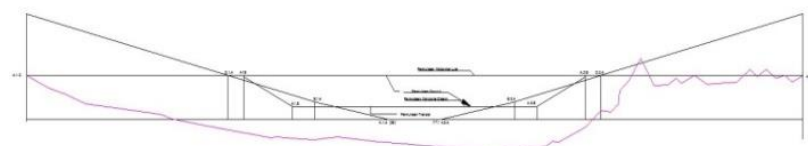

Gambar 8. Potongan memanjang KKOP terhadap topografi

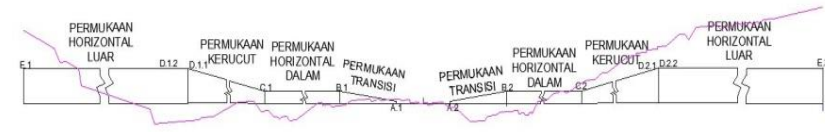

Gambar 9.Potongan melintang KKOP terhadap topograf

Catatan : Garis berwarna merah adalah bentuk topografi dangaris berwarna hitam adalah batas KKOP

Untuk memenuhi prosedur keselamatan operasi penerbangan, jika ada benda yang menghalangi kawasan keselamatan operasi penerbangan, perlu di tambahkan obstacle light pada penghalang tersebut. Berdasarkan SNI 03-7051-2004 tentang pemberian tanda dan pemasangan lampu halangan di sekitar bandara, ketinggian topografi lebih dari $150 \mathrm{~m}$ dari permukaan tanah pada runway sehingga perlu dipasang jenis lampu III. Jenis lampu III diletakkan pada dataran tinggi yang melebihi $150 \mathrm{~m}$ dengan warna lampu putih berkedip-kedip. Intensitas cahaya mada lampu antara $2000 \pm 25 \%$ cd dan dengan jumlah kedipan antara $40-60$ kali permenit. Antara puncak tertinggi dengan batas permukaan horizontal perlu di beri lampu dengan jarak maksimal 45m.Obstacle light (ditunjukkan dengan titik merah) dapat ditempatkan pada daerah sebagai berikut pada gambar 10 .

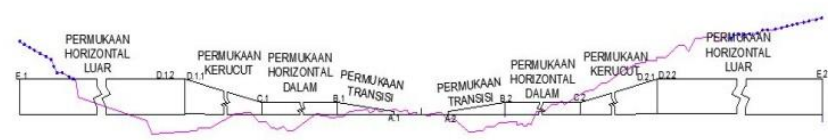

Gambar 10. Pemasangan Obstacle Light

Sehingga dapat disimpulkan bahwa pada arah memanjang runway, kawasan keselamatan operasi penerbangan Bandara Abdul Rachman Saleh terhadap topografi memenuhi syarat dan dapat menjamin keselamatan operasi penerbangan. Sedangkan, pada arah melintang runway, kawasan operasi penerbangan Bandara Abdul Rachman Saleh terhadap topografi tidak memenuhi,karena elevasi topografi lebih tinggi dari pada elevasi KKOP. Perlu di tambahkan obstacle light pada penghalang dengan jenis lampu III berwarna putih dengan jarak maksimal $45 \mathrm{~m}$ antar lampu dan jumlah kedipan 40-60 kali permenit. 


\section{B. Analisis Pola Pergerakan Masing-masing Pesawat} terhdap Topografi

Karakteristik pergerakan pesawat yang beroperasi di Bandara Abdul Rachman saleh perlu dilakukan analisa dengan tujuan untuk mengetahui berapa ketinggian dan sudut serta jarak masing-masing pesawat saat kondisi take off, lift off, climb out, dan cruise, dan kemudian dapat dilakukan koreksi terhadap ketinggian topografi dan batas KKOP.

Dalam melakukan evaluasi, data pokok yang dibutuhkan adalah aircraft performancelflash masing-masing pesawat. Berikut inigambar 4.15 adalah flash pada pesawat Airbus A320.

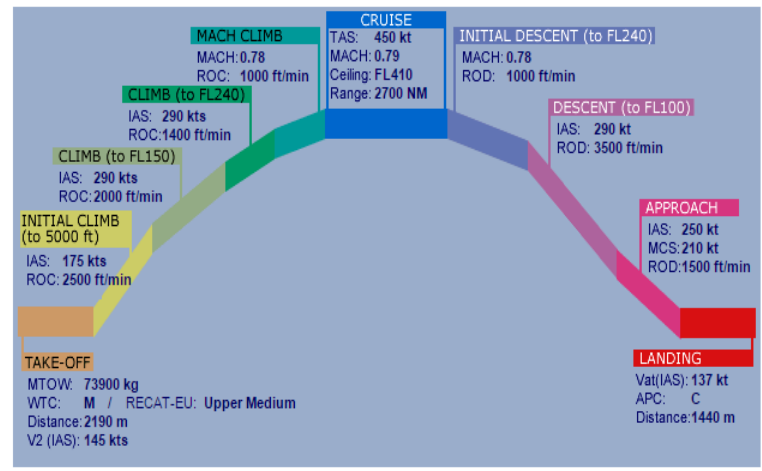

Gambar 11. Flash pada pesawat Airbus A320 [4].

Dari flash didapatkan pola dengan karakteristik pada tabel 3 berikut

Tabel 3.

hasil perhtungan pola pergerakan pesawat

\begin{tabular}{|c|c|c|c|c|c|c|c|c|c|c|c|}
\hline \multirow{3}{*}{ Airbus A320 } & \multirow{3}{*}{$\begin{array}{c}\text { Tinggi } \\
1 \\
\mathrm{ft} \\
\end{array}$} & \multirow{3}{*}{$\begin{array}{c}\text { Beda } \\
\text { Tinggi } \\
2 \\
\text { ft }\end{array}$} & \multicolumn{3}{|c|}{ IAS } & \multirow{3}{*}{\begin{tabular}{|c|} 
ROC \\
4 \\
$\mathrm{ft} / \mathrm{min}$
\end{tabular}} & \multicolumn{3}{|c|}{ Jarak } & \multirow{3}{*}{$\begin{array}{c}\text { Sudut } \\
\mathbf{6} \\
\text { degree }\end{array}$} & \multirow{3}{*}{ 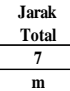 } \\
\hline & & & \multicolumn{3}{|c|}{3} & & \multicolumn{3}{|c|}{5} & & \\
\hline & & & kts & mach & $\mathrm{ft} / \mathrm{min}$ & & $\mathrm{nm}$ & $\mathrm{ft}$ & $\mathrm{m}$ & & \\
\hline Takeoff & & 0 & 145 & & 14684,15 & & & & 2190 & & 2190 \\
\hline Initial Clin & 00 & 5000 & 175 & & 17722,25 & 2500 & 5,83 & 444,03 & 10633,21 & 8,03 & 12823,21 \\
\hline \multirow[t]{2}{*}{ Climb } & 15000 & 10000 & 290 & & 29368,30 & 2000 & 24,17 & 146839,57 & 44051,87 & 3,90 & 56875, \\
\hline & & 9000 & 290 & & 29368,30 & 0 & 31,07 & 7793,73 & 56638,12 & 2,73 & 113513,20 \\
\hline Mach Climb & 41000 & 17000 & & 0,87 & 58742,14 & 1000 & 0,00 & 998616,36 & 299584,91 & 0,98 & 413098, \\
\hline Cruise & 41000 & & & \begin{tabular}{|l|l|}
0,78 \\
\end{tabular} & 52665,37 & 450 & 2700,00 & 0,00 & 5000400,00 & 0,00 & 5413498,11 \\
\hline Initial Descent & 24000 & 17000 & & 0,78 & \begin{tabular}{ll|l}
52665,37 & \\
\end{tabular} & 1000 & 0,00 & 895311,22 & 268593,37 & 1,09 & 5682091, \\
\hline descent & 10000 & 14000 & 290 & & 29368,30 & 3500 & 19,33 & 117471,65 & 35241,50 & 6,80 & 5717332 , \\
\hline approac & 10000 & 10000 & 250 & & 25317,50 & 1500 & 27,78 & 168781,11 & 50634,33 & 3,39 & 5767967 \\
\hline Landing & - & . & 137 & & 13873,99 & & 0,00 & 0,00 & 1440,00 & 0,00 & 769407 \\
\hline
\end{tabular}

C. Analisis Pola Pergerakan Masing-masing Pesawat terhdap Topografi

Analisis kesesuaian pergerakan masing-masing pesawat yang beroperasi akan dievaluasi terhadap topografi memanjang searah dengan aprroach runway. Dapat dilihat pada gambar 4.18 menunjukkan bahwa jarak dari tengah runway ke arah 35 sepanjang $16.2 \mathrm{~km}$ dan ke arah 17 sepanjang $16.2 \mathrm{~km}$.

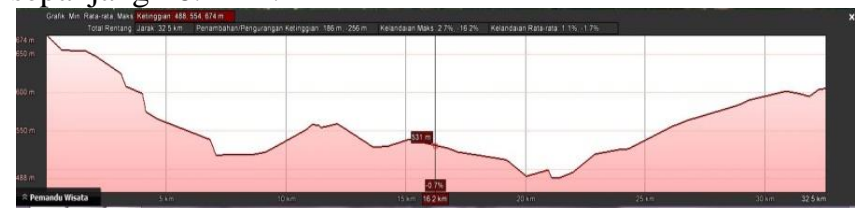

Gambar 12. Topografi kawasan bandara pada arah runway 35-17 [5]

Gambar diatas menunjukkan elevasi topografi bandara Abdul Rachman Saleh, selanjutnya dilakukan evaluasi terhadap ketinggian pesawat liftoff. Jika elevasi permukaan tanah ditambah dengan jarak ijin ketinggian $(10.7 \mathrm{~m})$ antara permukaan tanah dan pesawat memenuhi syarat, maka untuk pola pergerakan pesawat selanjutnya yang lebih tinggi, tidak akan mengganggu keselamatan penerbangan.

Dicontohkan jenis pesawat boeing 737-800 dengan take off distance 2300 meter dan mengalami lift off menuju ketinggian $35 \mathrm{ft}(10,7 \mathrm{~m})$ ke arah runway $35-17$. Setelah diperhitungkan dan mendapatkan TOR sepanjang 2189.21 meter dengan sudut lift off5.5 $5^{\circ}$ maka dapat digambarkan sebagai berikut

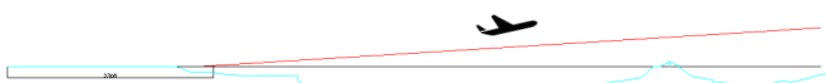

Gambar 13. Lift off suatu pesawat

Dari gambar 12, biru merupakan topografi permukaan tanah, hitam merupakan garis horizontal sejajar runway bandara, dan merah merupakan garis penerbangan pesawat setelah lift off (gradient of climb). Sehingga dapat disimpulkan bahwa pesawat tidak mengalami gangguan keselamatan saat melakukan lift off. Sehingga untuk polapola pergerakan pesawat berikutnya, tidak akan mengganggu keselamatan operasional.

\section{Analisis Pengaruh Berat Pesawat terhadap Ruang Udara}

Pesawat kritis yang beroperasi di Bandara Husein Sastra negera adalah Boeing 737-800.Jarak maksimum yang ditempuh pesawat dari Bandara Abdul Rachman Saleh ke Bandara Internasional Soekarno Hatta dengan jarak 377 nautical miles.Range/jarak yang telah diketahi dimasukkan ke dalam grafik Gambar 14. Dari grafik Gambar 14 dengan range $377 \mathrm{~nm}$ didapatkan OWE plus payload adalah 62000 kg dengan Brake Release Gross Weight adalah $68039 \mathrm{~kg}$. OEW boeing 737-800 adalah $41413 \mathrm{~kg}$.Sehingga payload pada penerbangan ini adalah sebagai berikut.

$$
\begin{aligned}
& \text { Payload }=\text { OEW plus payload } \text { pada grafik }- \text { OEW } \\
& \text { Payload }=62000-41413 \mathrm{~kg} \\
& \text { Payload }=20507 \mathrm{~kg}
\end{aligned}
$$

Dilakukan juga perhitungan konsumsi bahan bakar pesawat boeing 737-800 pada destinasi Malang Cengkareng sebagai berikut:

Konsumsi fuel $=$ Brake Release Gross Weight - Zero Fuel Weight Konsumsi fuel $=68039 \mathrm{~kg}-62000 \mathrm{~kg}$

Konsumsi fuel $=6039 \mathrm{~kg}=7365$ liter $($ Masa jenis avtur $=0.820 \mathrm{~kg} /$ liter $(6.84 \mathrm{lb} / \mathrm{US}$ gal $))$

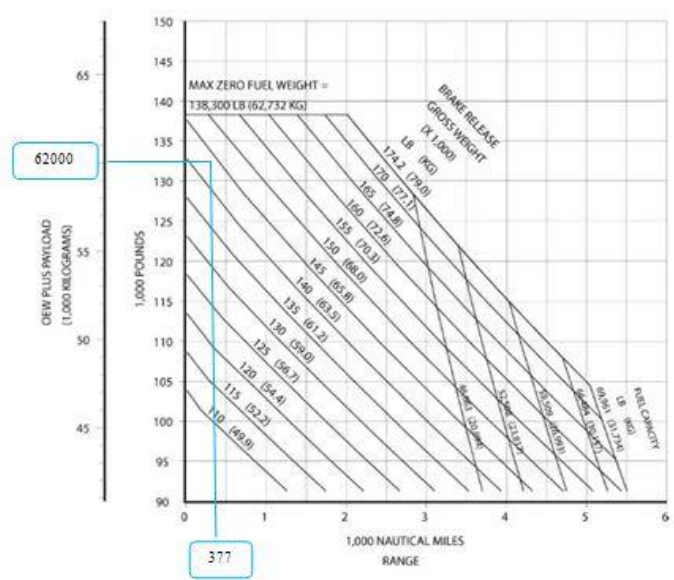

Gambar 14. Grafik perngaruh range dan payload pesawat boeing 737-800 [6]

Dengan Take off distance $2189.2 \mathrm{~m}$, maka dapat dilihat pada gambar grafik15bahwa dengan elevasi runway $528 \mathrm{~m}$ diatas permukaan air laut, maka seharusnya Operational Takeoff Weight adalah 68000kg. Namun berdasarkan klasifikasinya, dalam rute penerbangan ini berat pesawat mencapai $68039 \mathrm{~kg}$.Sehingga maximum payload pada penerbangan ini sebagai berikut. 
Max Payload $=$ AGW - bahan bakar - OWE

Max Payload $=(68000-6039-41413) \mathrm{kg}$

Max Payload $=20548 \mathrm{~kg}$

Destinasi pesawat dari Bandara Abdul Rachman Saleh menuju Bandara Internasional Soekarno Hatta memerlukan waktu 95 menit ( 1 jam 35 menit) dengan Boeing 737-800 sehingga kecepatan rata-rata pesawat tersebut adalah 3,9 $\mathrm{nm} /$ menit.Dalam radius destinasi $377 \mathrm{~nm}$ pesawat dapat menghabiskan bahan bakar sebesar 7365 liter,sehingga konsumsi bahan bakar pesawat per panjang destinasi yang ditempuh adalah 19,54 liter/nautical miles. Fuel cadangan pada pesawat berdasarkan CASR (Civil Aviation Safety Regulation) part 91 adalah30 menit dengan kecepatan normal.Sehinggafuel cadangan yang diperlukan oleh pesawat adalah $\mathbf{2 2 8 6}$ liter.

\section{E. Pengaruh Kondisi Cuaca terhadap Pergerakan Pesawat}

Kondisi cuaca termasuk salah satu faktor yang mempengaruhi kapasitas Bandara sebagai dasar untuk pengembangan bandar udara di masa mendatang dalam menghadapi pertumbuhan lalu lintas.Fenomena cuaca yang berpengaruh terhadap operasi penerbangan terutama di bandar udaraadalah ceiling (tinggi dasar awan) dan visibility (jarak pandang).

$$
\text { Tabel } 4
$$

Kapasitas Pergerakan Pesawat di Bandara Abdul Rachman Saleh

\begin{tabular}{|c|c|c|c|c|c|c|c|c|c|c|c|c|}
\hline \multirow{2}{*}{\begin{tabular}{|c|} 
Jam \\
Operasional
\end{tabular}} & \multirow{2}{*}{$\begin{array}{l}\text { Suhu } \\
\text { atata-Rata } \\
\text { ("c) }\end{array}$} & \multirow{2}{*}{\begin{tabular}{|c}
$\begin{array}{c}\text { Kelembapan } \\
\text { Rata-Rata }\end{array}$ \\
(\%)
\end{tabular}} & \multirow{2}{*}{\begin{tabular}{|c|}
$\begin{array}{c}\text { Tutupan } \\
\text { Awan }\end{array}$ \\
$(\%)$ \\
\end{tabular}} & \multirow{2}{*}{\begin{tabular}{|c}
$\begin{array}{c}\text { Jark Pandang } \\
\text { Rata-Rata }\end{array}$ \\
$(\mathrm{km})$ \\
\end{tabular}} & \multirow{2}{*}{$\begin{array}{l}\text { Efektif } \\
\text { Operasi } \\
\text { (menit) }\end{array}$} & \multicolumn{6}{|c|}{ Jadwal Penerbangan } & \multirow{2}{*}{$\begin{array}{c}\text { Ketersediaan } \\
\text { Slot Jadwal }\end{array}$} \\
\hline & & & & & & \begin{tabular}{|l|} 
Departures \\
\end{tabular} & Aircraft & \begin{tabular}{|l|l|} 
Flight \\
\end{tabular} & Arrivals & \begin{tabular}{|l|} 
Aircraft \\
\end{tabular} & Flight & \\
\hline $\begin{array}{c}\text { Pagi } \\
07.00-10.00\end{array}$ & 27 & 67 & 75 & 7,1 & 45 & $\begin{array}{l}8: 30 \\
8: 40 \\
9.25\end{array}$ & \begin{tabular}{|l|}
8738 \\
8738 \\
$A 320$ \\
\end{tabular} & \begin{tabular}{|l|l|}
$S 251$ \\
S.252
\end{tabular} & $\begin{array}{l}8: 55 \\
9: 15 \\
\end{array}$ & $\begin{array}{ll}\text { A320 } & \\
\text { A320 } & \\
\end{array}$ & \begin{tabular}{|l|} 
a, 69243 \\
107581 \\
\end{tabular} & 5 \\
\hline \begin{tabular}{c|} 
Siang \\
$10.00-13.00$
\end{tabular} & 28 & 65 & 82 & 6,1 & 33 & $\begin{array}{l}10: 30 \\
10: 55 \\
12: 45 \\
12: 45 \\
\end{array}$ & \begin{tabular}{|c|}
$32 \mathrm{~A}$ \\
B738 \\
B738 \\
AT4 \\
\end{tabular} & \begin{tabular}{|l|}
107580 \\
GA291 \\
SS248 \\
IW1819 \\
\end{tabular} & \begin{tabular}{|l|}
$10: 05$ \\
$12: 05$ \\
$12: 25$ \\
$12: 20$ \\
$12: 25$ \\
\end{tabular} & \begin{tabular}{|c|} 
B738 \\
B738 \\
B738 \\
AT4 \\
B738 \\
\end{tabular} & \begin{tabular}{|l|} 
GA290 \\
SJ246 \\
SJS247 \\
IW1818 \\
GA292 \\
\end{tabular} & 9 \\
\hline \begin{tabular}{c|} 
Sore \\
$13.00-16.00$
\end{tabular} & 24 & 79 & 82 & 4,3 & 32 & \begin{tabular}{|l|l|}
$13: 10$ \\
$14: 15$ \\
1430 \\
$14: 30$ \\
$14: 45$ \\
$15: 10$ \\
\end{tabular} & \begin{tabular}{|c|} 
7738 \\
AT4 \\
$32 \mathrm{~A}$ \\
320 \\
B738 \\
8738 \\
\end{tabular} & \begin{tabular}{|l|} 
GA29293 \\
IW1841 \\
ID7582 \\
QG145 \\
SA2934 \\
S.2249 \\
\end{tabular} & \begin{tabular}{|l|l|}
$13: 50$ \\
$14: 00$ \\
$14: 00$ \\
$14: 15$ \\
$14: 30$ \\
\end{tabular} & \begin{tabular}{|c|c|} 
AT4 \\
B738 \\
A320 \\
$32 A$ & 1 \\
B738 & \\
\end{tabular} & \begin{tabular}{|l|} 
IW1840 \\
GA29294 \\
QG1414 \\
$1 D 7581$ \\
S.248 \\
\end{tabular} & 11 \\
\hline
\end{tabular}

Kapasitas 25 pergerakan per jam tersebut diterapkan pada pukul 08.30 - 15.10WIB sebab hanya satu runway yang beroperasi dengan memperhitungkan terbatasnya visibilitas saat senja. Pada kolom berwarna merah merupakan pesawat di Bandara Abdul Rachman Saleh yang mengalami touch and go dimana waktu yang dilakukan selama 10 menit, maka dengan kondisi cuaca pada pagi hari dengan suhu rata-rata $27^{\circ} \mathrm{C}$, jarak pandang $7,1 \mathrm{~km}$ dan waktu efektif selama 45 menit Bandara Abdul Rachman Saleh dapat menambah jam operasinal pesawat di bandara Abdul Rachman Saleh. Upaya peningkatan kapasitas pergerakan di Bandara Abdul Rachman Saleh memang tidak mudah.Karena mencakup beberapa aspek dan mengharuskan kerjasama disiplin dengan berbagai pihak seperti misalnya maskapai penerbangan, pilot dan ground handling serta penumpang.

\section{KESIMPULAN DAN SARAN}

\section{A. Kesimpulan}

Berdasarkan hasil analisa pada bab sebelumnya, maka pada bab ini dapat diambil kesimpulan sebagai berikut

1. Hasil analisis Kawasan Keselamatan Operasi Penerbangan (KKOP) dengan topografi wilayah sekitar Bandara Abdul Rachman Saleh menunjukkan bahwa:

a. Pada arah memanjang runway, kawasan keselamatan operasi penerbangan Bandara Abdul Rachman Saleh terhadap topografi dapat menjamin keselamatan operasi penerbangan. b. Pada arah melintang runway, kawasan operasi penerbangan Bandara Abdul Rachman Saleh terhadap topografi tidak memenuhi, karena elevasi topografi lebih tinggi dari pada elevasi KKOP.

c. Perlu di tambahkan obstacle light pada penghalang (elevasi topografi yang lebih tinggi dari kawasan horizontal luar KKOP) dengan jenis lampu III berwarna putih dengan jarak maksimal $45 \mathrm{~m}$ antar lampu dan jumlah kedipan 40-60 kali permenit.

2. Analisis berat pesawat terhadap ruang udara, menunjukkan bahwa:

a. Sudut lift off ditentukan dengan menggunakan angle of attack untuk mendapatkan take of run.

b. Dengan take off distance 2300 meter dan mengalami lift off menuju ketinggian $35 \mathrm{ft}(10,7 \mathrm{~m})$ ke arah runway 35-17. Setelah diperhitungkan dan mendapatkan TOR sepanjang 2189.21 meter dengan sudut lift off $5.5^{\circ}$.

3. Destinasi pesawat dari Bandara Abdul Rachman Saleh menuju Bandara Internasional Soekarno Hatta memerlukan waktu 95 menit (1 jam 35 menit) dengan Boeing 737-800 sehingga kecepatan rata-rata pesawat tersebut adalah 3,9 $\mathrm{nm} /$ menit. Dalam radius destinasi $377 \mathrm{~nm}$ pesawat dapat menghabiskan bahan bakar sebesar 7365 liter, sehingga konsumsi bahan bakar pesawat per panjang destinasi yang ditempuh adalah 19,54 liter/nautical miles. Fuel cadangan pada pesawat berdasarkan CASR (Civil Aviation Safety Regulation) part 91 adalah 30 menit dengan kecepatan normal. Sehingga fuel cadangan yang diperlukan oleh pesawat adalah 2286 liter.

4. Kondisi cuaca termasuk salah satu faktor yang mempengaruhi kapasitas bandara sebagai dasar untuk pengembangan bandar udara di masa mendatang dalam menghadapi pertumbuhan lalu lintas. Kapasitas 25 pergerakan per jam tersebut diterapkan pada pukul 08.30 - 15.10WIB sebab hanya satu runway yang beroperasi dengan memperhitungkan terbatasnya visibilitas saat senja. Pada kolom berwarna merah merupakan pesawat di Bandara Abdul Rachman Saleh yang mengalami touch and go dimana waktu yang dilakukan selama 10 menit, maka dengan kondisi cuaca pada pagi hari dengan suhu rata-rata $27^{\circ} \mathrm{C}$, jarak pandang $7,1 \mathrm{~km}$ dan waktu efektif selama 45 menit Bandara Abdul Rachman Saleh dapat menambah jam operasinal pesawat di bandara Abdul Rachman Saleh.Upaya peningkatan kapasitas pergerakan di Bandara Abdul Rachman Saleh memang tidak mudah. Karena mencakup beberapa aspek dan mengharuskan kerjasama disiplin dengan berbagai pihak seperti misalnya maskapai penerbangan, pilot dan ground handling serta penumpang.

\section{B. Saran}

Beberapa saran yang diberikan penulis pada studi ini adalah sebagai berikut.

1. Pada arah potongan meintang KKOP, ketinggian topografi melebihi batas KKOP. Oleh karena itu, penulis menyarankan untuk ditambahkan Tanda dan Lampu pada penghalang (Obstacle Light) di sekitar daerah penghalang.

2. Dalam studi ini tidak diperhitungkan kelayakan secara ekonomi penerbangan. Sehingga penulis merekomendasikan untuk melakukan evaluasi tentang ekonomi penerbangan. 
3. Analisis terhadap jarak pandang untuk Bandara dengan sistem VFR perlu dikaji lebih dalam berkaitan dengan penjadwalan.

\section{DAFTAR PUSTAKA}

[1] F. A. A. 2005, Advisory Circular 150/5325-4B, Runway Length Requirement for Airport Design. Washington D.C.: US Department of Transportation, 2005.

[2] D. J. P. Udara, SNI 03-7112-2005. Kawasan Keselamatan Operasi
Bandara.Departemen Perhubungan RI. Jakarta, 2004.

[3] K. D. J. P. U. N. SKEP/48/III/2001, Pedoman Penelitian Rancangan Keputusan MenteriPerhubungan Tentang Kawasan Keselamatan Operasi Penerbangan di Bandar Udara dan Sekitarnya. Jakarta, 2001

[4] "Http://aircraftperformance.com." [Online]. Available: http://aircraftperformance.com.

$$
\text { E. }
$$

Malang,

Available: https://www.google.co.id/maps/place/Malang>." .

[6] S. B. F. E. Horonjeff, Robert. Mc Kelvey, Francis X. Sproule, William J. Young, Planning and Design of Aiports. New York: Mc Graw - Hill Inc, 2010. 